\title{
DeVelopment of TIMSS Model TeSt to MeAsure The NuMber SENSE Ability OF Junior High School Students
}

\author{
Riyanti Nurdiana \\ Tanjungpura University, Pontianak, Indonesia \\ E-mail: riyantinurdiana@yahoo.com
}

\begin{abstract}
TIMSS results in the number content and number sense ability of students in Indonesia are still low. This research aims to train and familiarize students of the junior high school to work on problems in TIMSS using number sense abilities. The process of developing test instruments in this research was through the stages of the Plomp development model that are (1) preliminary investigation phase; (2) design phase; (3) realization phase; (4) test, evaluation and revision phase, and (5) implementation phase. This research produced a good quality test. The test instrument has met the criteria of valid, reliable, objective and practical included 4 item with high validity categories and 14 items of medium validity categories. The level of reliability is very high with $r_{11}=0.884$, objective from the results of reliability and practical from the student response questionnaire analysis with the average student giving a positive response of $72.1 \%$. The results of the research reveal that the test instruments that can measure the number sense ability are in the low category with an average percentage in the overall number sense indicator of $44.26 \%$ and from the interview results, students have not used all the indicators of the number sensing ability well.
\end{abstract}

Keywords: Development of Plomp; TIMSS Test; Number Sense Ability

\section{INTRODUCTION}

According to NCTM (2000: 32), applying for numbers in various types must become the main part of mathematics instruction starting from elementary school, by extending the whole number to integers, developing students' intuition about the sequence and magnitude at the junior high school level. In the senior high school, students are introduced to be able to use variables and functions in applying the relationship between the set of numbers and see the nature of number class. Numbers have become the basis of mathematics. The principles of solving problems in algebra are the same as the structure of properties in a number system. In geometry and measurement, properties are explained by numbers. All analysis data also involve numbers. Through problem solving, students can explore and strengthen their understanding of numbers. From kindergarten to $12^{\text {th }}$ grade, students learn how to understand numbers; how to apply it with objects, numbers or number lines; how to connect one number to another; how numbers are embedded in systems that have properties and structures; and use numbers and operations in problem solving. Therefore, a study of the number sense ability of students needs to be carried out to see to what extent students can use their number sensing ability in various problem situations with numbers.

Students with a good number sense can think and reason flexibly about numbers, use numbers to solve problems, find reasonable answers, understand how numbers can be separated and put together in different ways, see relationships between number operations, determine mentally and make reasonable estimates, so students have good intuition about numbers and see the use of numbers.

Mullis et al. (2009: 31) argued that the students' number sense ability can be measured in the number content domain in the TIMSS test because on the cognitive subject which is divided into several more specific topics, there are several indicators of the number sense ability to classify/order, compute and justify, the number content in TIMSS includes understanding of numbers, how to present numbers, relationship between numbers and number systems. In this content, the eighth-grade students are expected to have number sense and numeracy skills, understanding the meaning of number operations, and students must be able to use numbers and their operations to solve problems.

The results of the number domain in TIMSS show that the students' number sense ability in Indonesia is not well developed. The TIMSS results show that the score of the number content ability is low and below the international 
achievement standard (Mullis et al., 2000; Mullis et al., 2009; Mullis et al., 2012). The results of the 2011 TIMSS study of the material on number indicate that only $57 \%$ of Indonesian students were able to answer the decimal questions despite the fact that the international average had reached $72 \%$. The same thing was found in terms of the percentage where only $20 \%$ of Indonesian students were able to answer correctly from the average of $32 \%$ of the international students, as well as regarding the fraction in which they only reached $10 \%$ of the $23 \%$ of the international average, where overall the ability of the Indonesian students in the material on number in the 2011 TIMSS study achieved the lowest ranking.

The TIMSS results were supported by interviews and preliminary investigation conducted by the researchers on March 2, 2018, on teachers of the mathematics subject and 15 students of Private Junior High School Gembala Baik in Pontianak which showed that the TIMSS questions were rarely given to students and the students' number sense was not well developed. Based on the interviews with the teachers, for the purpose of evaluating the questions, they had not used questions with the characteristics of TIMSS whose characteristics are more complex or varied, contextual, demanding reasoning, argumentation, and creativity in solving problems. The teachers had never developed questions that could measure the level of students' ability of those who only know the facts, procedures or concepts to those who could use it to solve simple problems to problems that require high reasoning. Teachers have never used instructional methods that can develop students' number sense and trained students with number sense questions because teachers did not know what number sense is, so the students' number sense ability received less attention. As a result, students can only work on problems that are not much different from the examples in books and worksheets or routine problems.

The results of the test in the preliminary investigation show that students are not used to working on TIMSS questions and the students' number sense ability is not well developed by paying attention to the reasons for answers and procedures that students use. Students still focus on procedural calculations commonly taught by teachers. In fact, it would be better if the question can provide more information to the teacher in addition to the student's scores, namely the level of student's particular ability such as the number sense ability so that the teacher can guide students to develop this skill, and students will be familiar with the TIMSS model problems.

Based on the facts that things did not happen according to expectations, the solution to the problem of TIMSS number content domain and the low ability of number sense among the students is by getting students used to working on the TIMSS model test to measure their number sense ability. If the students' number sense ability is low, it can be followed up immediately in the next research.

A study by Lessani et al. (2014) concluded that teachers who are used to giving TIMSS questions have a significant impact on student achievement. The theory of Stanislas
(2011: 139) stated that students will use number sense when dealing directly with numerical situations or in other words the number sense ability will develop if triggered by a context that requires mathematics in which a person creates a relationship between numbers. This will make children think about numbers in a flexible way so they need to think about activities that require them to encounter numbers in a variety of different situations and the material provided must also expand their horizon, not merely solving problems with procedural methods. Number sense appears as a result of learning rather than through direct teaching. Teachers can develop number sense by providing mathematical tasks that encourage students to make relationships from personal experiences and previous instruction.

The description above shows a gap between expectation and reality. Therefore, the researchers seek to reveal the students' number sense ability through the TIMSS test model developed, and introduce students to TIMSS questions in daily instruction. Therefore, the researchers are interested in conducting a TIMSS model test development study to measure the ability of the number sense of students in junior high schools.

\section{RESEARCH METHOD}

The method used in this research is the Plomp model research and development (R\&D). The Plomp model development design (Hobri, 2009: 24-26) has 5 phases in its implementation. The phases of the Plornp model are (1) preliminary investigation phase, (2) design phase, (3) realization/construction phase, (4) test, evaluation and revision phase, and (5) implementation phase. The activities or phases of the research can be described in Fig. 1.

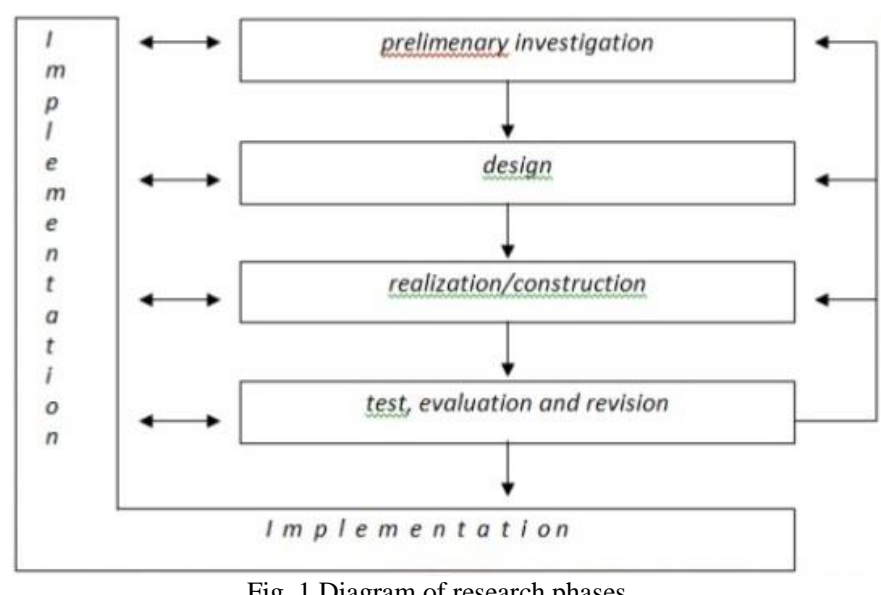

Fig. 1 Diagram of research phases

The subjects of limited try-out in this study were students of Grade VII E of the State Junior High School (SMP Negeri) 3 Pontianak and students of Grade VII C of Private Junior High School (SMP) Santu Petrus Pontianak in the academic year of 2017/2018. The subjects of the field try-out research in this study were students of VIII E of the Private Junior High School (SMP) Gembala Baik Pontianak in the academic year of 2018/2019. The researchers took the Grade VIII students as research subjects because the research was 
carried out at the beginning of the new school year where students had studied the material on integer in the previous semester of Grade VII in the previous school year. The procedure in this research consists of 5 phases as follows:

\section{Preliminary Investigation Phase}

This is the phase of the preliminary investigation and analysis of things needed before the test was developed. The things that can be done include material analysis, analysis of teacher needs and analysis of students.

\section{Design Phase}

After the analysis process in the preliminary investigation phase is completed, the next is the design phase which is the phase of designing the questions based on the TIMSS model and contains an indicator of number sense ability. The procedure in designing the questions includes paying attention to the character of the TIMSS model, determining the type of test, preparing the outline, writing questions, making alternative answers and scoring guidelines.

\section{Realization/Construction Phase}

The realization/construction phase is carried out by making instruments that have been prepared based on the criteria in the design phase so that the TIMSS model test instrument is made which contains number sense ability indicators and alternative answers along with scoring guidelines. In this phase, the test instrument is called prototype 1 .

\section{Test, Evaluation and Revision Phase}

In this phase, 2 main activities were carried out namely; (1) validation activities; before the test validation activities were carried out, a validation instrument was first developed. The type of instrument used in this phase was the validation sheet. The instruments, before being used, were first tried out on small-scale limited subjects (try-out 1) of 15 students of State Junior High School 3 Pontianak. The results were analyzed and revised especially questions that could not be used; the revised results produced prototype 2 then validated by the experts to examine the validity of the instrument that will be used to measure the set aspects, in terms of the clarity of the formulated measurement objectives, the suitability of the questions for each aspect, language use, and clarity of the instrument usage instructions. The test content validation activities were carried out by providing validation instruments to the experts. The experts acting as the validators were lecturers of Mathematics Education and mathematics teachers in junior high schools. Suggestions from validators are used as a basis for improvement or revision of the test. (2) try-out activities; after the revision and validation were completed by the validators, the prototype 3 was produced; then large-scale limited try-out (Try-out 2) was carried out to determine the quality of the test and the item validity, reliability, objective and practicality. Students gave a response after completing the test by filling out the response questionnaire to determine the practical aspects of the test. To determine the quality of the items was by getting the students' answers in the try-out analyzed to determine the item validity and reliability. In terms of objectivity, it was seen from the reliability generated. In terms of practicality, it was seen from the results of the response questionnaire analysis. After being analyzed, if it meets the quality test criteria which meet the four criteria of being valid, reliable, objective and practical, the final prototype is produced and can be implemented.

\section{Implementation Phase}

After each phase is passed in the test development procedure, starting from the preliminary investigation stage to the test, evaluation, and revision of all components of the research instrument. If there is an improvement (revision) or change then a review is immediately carried out on the parts of the research instrument. Then field try-out was implemented on the research subjects. The test results of the tests were analyzed to find out how much the number sense ability was seen from the results of the overall students' test scores and interviews with students to find out more about the students' number sense ability.

\section{RESULT AND DISCUSSION}

The results of the research were obtained from each phase of the implementation of problem development activities using the Plomp development model with instruments in the form of tests and interviews. These results were used to answer the formulation of the problem in this research, which is about the process of developing a TIMSS model test that can measure students' number sense ability, quality of questions and the number sense ability of the students of Private Junior High School Gembala Baik Pontianak.

In the first phase (preliminary investigation), three results of analysis activities were obtained, namely (1) material analysis, conducting activities to identify the main concepts that will be used in the test on the Grade VII materials. Based on the material analysis activities, it was found that the material used in the development of the TIMSS model test instrument was the number of content in accordance with the material and the basic competencies in the 2013 curriculum for mathematics subject in Grade VII of the odd semester on the material of integers; (2) the analysis of teacher's needs to find out the teacher's needs for the questions was performed through interviews with mathematics teachers who taught at the Private Junior High School Gembala Baik Pontianak. The results of the analysis of teacher's needs showed that the questions used by the teacher were only questions with the cognitive domain of understanding and problem solving, not questions with cognitive domains of knowledge, application, and reasoning which are cognitive domains in the TIMSS questions, so TTMSS questions with various cognitive domains were needed to enable students to learn new knowledge; (3) analysis of students was performed by reviewing student characteristics including the students' number sense ability in working on the problem by being given several tests in the preliminary investigation. From the results of the preliminary investigation, it can be concluded that the 
students' number sense ability is low because out of the 15 students no one could solve both problems of number sense correctly.

In the second phase (design), the activity was designing a set of questions consisting of problem outlines, items, alternative answers, and scoring guidelines. In the third phase (realization), the results of the development of test instruments presented based on the design in the design phase are called prototypes. In the fourth phase (test, evaluation, and revision), the test items were tried-out, revised to produce prototype 2 and then validated and retried-out to produce prototype 3 which has a quality test that meets 4 aspects, namely validity, reliability, objectivity, and practicality. In the fifth phase (implementation), the prototype 3 produced a final prototype that was implemented in the research subject, namely Grade VIIl E at the Private Junior High School Gembala Baik Pontianak with a total of 30 students. Overall, the final prototype is the same as the prototype 3 .

The test quality analysis resulted in 4 items having validity with high criteria (items $1,9,15$ and 16) and 14 items with moderate validity (items $2,3,4,5,6,7,8,10,11$, $12,13,14,17$ and 18). The reliability test results of the items used the alpha formula calculation. For items on the number sense ability of the TIMSS model, the $r_{11}$ value $=0.884$ which is classified into the criteria of "very high". From the aspect of reliability, the test has a very high reliability so it can be retried-out and with its reliability criteria, the objectivity aspect has also been met based on the theory. The percentage of the response questionnaires was $72.1 \%$ indicating a positive response. So, the practical aspect has been met because more than $50 \%$ gave positive responses.

The students' number sense ability can be measured through test results in the field try-out by analyzing students' scores and grades. To state that the average ability of number sense among the research subject was 55.7, it is acceptable to use the $z$-distribution test and make a hypothesis stating that the average ability of the students' number sense is 60 with a standard deviation of 16.53 .

To determine the level of students' number sense ability at the Private Junior High School Gembala Baik Pontianak was by calculating the average percentage of students' ability on the five indicators of number sense based on the score obtained on each indicator that can be seen in Fig. 2.

From Fig. 2, the percentage graph of the achievement of students' number sense on the five indicators, it can be seen that the percentage of number meaning is categorized as moderate, the number relationships indicator is categorized as low, the number magnitude indicator is categorized as moderate, the number operation indicator is categorized as low and the number referent is moderate. The students' number sense ability in answering TIMSS questions is low according to the 2015 TIMSS category with the percentage of achievement of all indicators being $44.26 \%$.

Based on the results of the research described above and the score of the overall test results, it can be seen that the students' number sense ability in solving the TIMSS model problems is low. The score of the overall test results is the total of scores from the five indicators of number sense, namely the number meaning, number relationships, number operation, and number referent. The following is the analysis of the results of the students' interviews on different indicators.

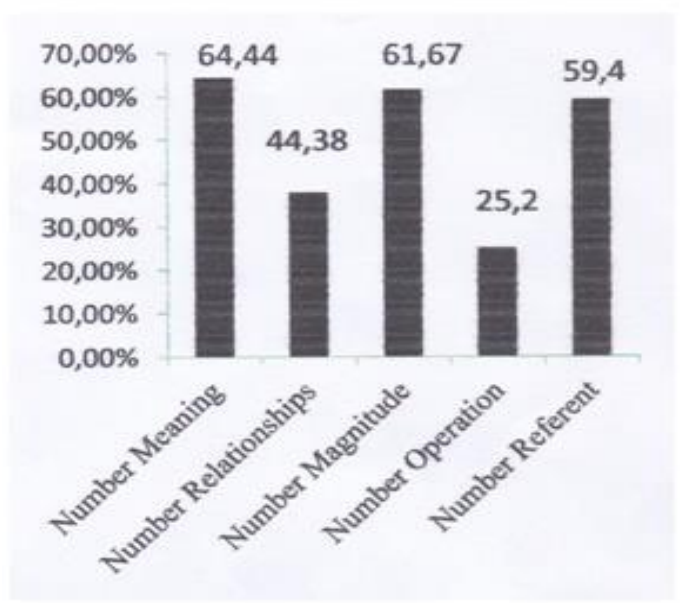

Fig. 2 Percentage of number sense ability

\section{Students' ability on the number meaning indicator}

Most students did not have difficulty with the test by finding the meaning of a known number, can put the number in the sequence, determine a number between the two numbers and determine many of the numbers that are compared. The difficulty the students had was that they did not understand the questions of the problem because they thought that there were no numbers between the fractions whose numerators are adjacent numbers and they could not reason for a certain number.

\section{Students' ability on the number relationships indicator}

Some students had difficulty in solving problems with a procedure that uses relationships between numbers, dealing with numbers previously known, changing various forms of number representation. The difficulty they had was that they did not understand how to determine the results of a negative number reduction operation and did not understand the relationship between the percentage that is not yet known to be used in the next process, students could not reason to find the relationship between numbers in the table. Some students understood the purpose of the questions by comparing and linking the previous and subsequent numbers and finding regular comparisons in the table.

\section{Students' ability on the number magnitude indicator}

Most students understood the questions using estimates, measurement tools, and counting. They used a ruler to estimate unknown sizes and then compare with the height of other known objects. Students used logical reasoning on the number of certain objects. They used existing numbers and are operated to produce the largest number. 


\section{Students' ability on the number operation indicator}

Most students did not understand the questions by using number operations for various numbers and their properties which can make it easy to calculate the final result. They did not understand number operation of the exponential number and its application to daily life such as volume. Students could not reason to find a more simple form of operation of certain numbers.

\section{Students' ability on indicator number referent}

Some students understood the questions by using addition and multiplication. They could find the same number of operation but the sign is different (positive and negative) and will be equal to zero. Students used their comprehension that numbers assigned to the opposite will produce an identity.

Based on the results of the description and analysis of the data, it can be seen that some things supported and were in line with the theory and previous research. Among them is that the teacher needs the TIMSS model to measure the ability of number sense to meet the demands of the 2013 curriculum which follows the development of the international curriculum. This is consistent with the curricula in developed countries such as the United States, Britain and Australia (NCTM, 1989; Wilfred, 1982; AEC 1991) which emphasize the importance of developing number mastery even from the elementary school level. The process of developing questions is a step that is in line with Marilyn (2007: 24) who stated that to improve the quality of students is by developing their number sense, familiarizing them with types of reasoning problems and various other cognitive domains so that they can generate thinking flexibly. This is what motivated the researchers to design types of the question with various cognitive domains such as the TIMSS model on number content with the hope that if the students routinely exercise with this type of questions, they can develop their number sense.

The results showed that the ability of the number sense of the Private Junior High School students of Gembala Baik in Pontianak was relatively low, meaning that the students were less familiar with the questions of the TIMSS model and did not use the number sense. The results of this research are in line with several existing studies, including research by Mcintosh \& Reys (1992), Tosto (2013), Gregory \& Benkov (2006) and Prasetyo \& Rudhito (2016) who said that students had difficulty solving the TIMSS model problems with number content and did not use the number sense to solve integer problems.

The results of the data analysis show that the number sense ability of each student is different. This is in accordance with Pilmer's (2008) opinion, namely the ability of number sense of each student is different because number sense develops along with students' experience and knowledge gained from formal or informal education. In the interview process and interview results, students with good number sense ability had confidence and were not confused when answering the steps taken in answering questions, could explain the concepts used, connected between numbers and used the characteristics of operations and number identity. Fosnot (2001) supported the results of this study by stating that students who have good number sense ability indirectly are flexible and confident and are able to overcome various kinds of questions related to numbers.

The results of the study show that the indicator of the students' number sense ability for number operation and number relationships is low compared to the other three indicators. For number relationships, students did not understand the relationship of a number with another for example if $50 \%$ is 10 then $100 \%$ is 20 . This is triggered by the lack of students' understanding of various integer representations ranging from decimal, fraction, percentage, comparison and exponent. For number operation, students' difficulties were caused by a lack of knowledge about operations that are suitable for use in solving problems in mathematics. In addition, most students experienced difficulties in understanding number relationships. Students rarely and even never answer the questions like the ones presented to them. This is in line with the results of Nurmaulisihitni's (2014) study stated that students in lower groups are very weak in number relationships and number operation.

The results of the data description, data analysis, and interviews explained that the number sense ability of the students of Private Junior High School Gembala Baik in solving the TIMSS problems of whole number material was low. One of the causes is that the teacher did not train and pay attention to the students' number sense ability even though in general students' number sense could be trained by the teacher, because if students are able to develop their number sense, teachers will also feel the benefits in the learning process. Based on the interviews, some students thought that the questions given were new and had never been given by the teacher before. This is in accordance with the results of interviews with the teachers in which they said that they did not have much time, ability and creativity to explore the students' number sense comprehensively. This statement is in accordance with the statement of Fosnot (2001) stated that the number sense ability can be trained for each child. A child is not born with the ability of number sense but the teacher has to explore the child's number sense. By studying the ability of students' number sense, teachers can learn the development of students' way of thinking, the strategies used and misconceptions that students have.

In this study, the Plomp development model was used only in the process of developing tests rather than developing models or learning methods that can improve students' number sense. This is one of the factors of the low ability of the students' number sense. In the Plomp phases of the preliminary investigation, test design, three-time try-outs, with repeated revisions producing prototypes and used for research, aim to measure number sense ability. This is in line with the research by Ruslan, Witra, and Darwis (2015) stated that test development aimed only to produce valid and reliable questions about the ability to understand concepts, principles, and skills in mathematics subject for seventhgrade students but did not improve students' ability. 


\section{IV.CONCLUSION}

Based on the problem, the results of data analysis, interviews, it can be concluded that: (1) the results of the needs analysis of the test consists of three activities, namely material analysis, teacher needs analysis and student analysis, (2) the TIMSS model test aims to measure the ability of number sense of junior high school students with good quality with regard to the valid, reliable, objective and practical aspects, (3) the ability of students' number sense of the research subjects showed a percentage of $44.26 \%$ which was classified as low with an average of 55.7. For each indicator of ability, the number sense, number relationships, and number operation are categorized as low while the number meaning, number magnitude, and number referent are categorized as a medium.

\section{REFERENCES}

Australian Education Council (AEC). 1991. A National Statement on Mathematics for Australian School. Melbourne: Education Council and Curriculum Coorporation.

Fosnot. 2001. Young Mathematicians at Work: Constructing Number Sense Addition and Substraction. Portsmounth, NH: Heineman.

Gregory \& Bankov. 2006. Exploring The Change in Bulgarian Eighth-Grade Mathematics Performance from TIMSS 1995 to TIMSS 1999 in S. J. Howie \& T. Plomp (Eds.), Contexts of Learning Mathematics and Science (p. 245-264). New York, NY: Routledge.

Hobri. 2009. Metode Penelitian Pengembangan. Jember: FKIP Universitas Jember.

Lessani, Abdolreza. et al. 2014. Effects of Malaysian Secondary Schools Mathematics Teachers Familiarity with TIMSS on Students Achievement in Mathematics. International Journal of Education and Research, 2(8): 99-110.

Marilyn, Burns. 2007. About Teaching Mathematics: A K-8 Resource. 3rd ed.Sausalito, CA: Math Solutions.
Mcintosh \& Reys. 1992. A Proposed Framework for Examining Basic Number Sense. For The Learning of Mathematics, 12(3), 2-8.

Mullis, et. al. 2000. TIMSS 1999 International Science Report. Chessnut Hill: Boston Collage.

Mullis, et. al. 2009. TIMSS 2011 Assessment Frameworks. Chestnut Hill, MA: TIMSS \& PIRLS International Study Center.

Mullis, et. al. 2012. TIMSS 2011 International Result in Mathematics. Chestnut Hill, MA: TIMSS \& PIRLS International Study Center.

NCTM. 1989. Curriculum and Evaluation Standards for School Mathematics. Reston.

NCTM. 2000. Principles and Standards for School Mathematics. Reston, VA: National Council of Teachers of Mathematics.

Nurmaulisihitni. 2014. Number Sense Bentukan Siswa dalam Menyelesaikan Soal Operasi Hitung Bilangan Bulat di Kelas VII Madrasah Tsanawiyah Negeri. (online). http:// www.jurnal.untan.ac.id. (accessed 23 Mei 2018).

Pilmer. 2008. Number Sense, Novia Scotia School for Adult Learning. Department of Labour and Workforce Development.(Online).http://www.gonssal.ca/docu ments/NumberSense.pdf/. (accessed 3 Juni 2018).

Prasetyo \& Rudhito. 2016. Analisis Kemampuan dan Kesulitan Siswa SMP dalam Menyelesaikan Soal Bilangan Model TIMSS. Jurnal Pengajaran MIPA, 21(2), 122-128.

Ruslan, Witra and Darwis. 2016. Pengembangan Tes Kemampuan Pemahaman Konsep, Prinsip dan Skill dalam Mata Pelajaran Matematika dikelas VII SMP. (online). http://www.eprints.unm.ac.id. (accessed 15 Juli 2018).

Stanislas. 2011. The Number Sense How The Mind Creates Mathematics. New York: Oxford University Press.

Tosto, Maria. 2013. Development and Validation of a Mathematics-number sense Web-based Test Battery. Universiti Teknologi Malaysia, Johor, Malaysia.

Wilfred, Cockroft. 1982. Mathematics Counts: Report of The Committee of Inquiry into The Teaching of Mathematics in Schools. London: HMSO. 